IZA DP No. 5570

Trust in Public Institutions over the Business Cycle

Betsey Stevenson

Justin Wolfers

March 2011 


\title{
Trust in Public Institutions over the Business Cycle
}

\author{
Betsey Stevenson \\ Wharton School, University of Pennsylvania, \\ CESifo and NBER \\ Justin Wolfers \\ Wharton School, University of Pennsylvania, \\ Brookings, CESifo, CEPR, NBER and IZA
}

\section{Discussion Paper No. 5570 \\ March 2011}

IZA

P.O. Box 7240

53072 Bonn

Germany

Phone: +49-228-3894-0

Fax: +49-228-3894-180

E-mail: iza@iza.org

\begin{abstract}
Any opinions expressed here are those of the author(s) and not those of IZA. Research published in this series may include views on policy, but the institute itself takes no institutional policy positions.

The Institute for the Study of Labor (IZA) in Bonn is a local and virtual international research center and a place of communication between science, politics and business. IZA is an independent nonprofit organization supported by Deutsche Post Foundation. The center is associated with the University of Bonn and offers a stimulating research environment through its international network, workshops and conferences, data service, project support, research visits and doctoral program. IZA engages in (i) original and internationally competitive research in all fields of labor economics, (ii) development of policy concepts, and (iii) dissemination of research results and concepts to the interested public.
\end{abstract}

IZA Discussion Papers often represent preliminary work and are circulated to encourage discussion. Citation of such a paper should account for its provisional character. A revised version may be available directly from the author. 
IZA Discussion Paper No. 5570

March 2011

\section{ABSTRACT}

\section{Trust in Public Institutions over the Business Cycle*}

We document that trust in public institutions - and particularly trust in banks, business and government - has declined over recent years. U.S. time series evidence suggests that this partly reflects the pro-cyclical nature of trust in institutions. Cross-country comparisons reveal a clear legacy of the Great Recession, and those countries whose unemployment grew the most suffered the biggest loss in confidence in institutions, particularly in trust in government and the financial sector. Finally, analysis of several repeated cross-sections of confidence within U.S. states yields similar qualitative patterns, but much smaller magnitudes in response to state-specific shocks.

JEL Classification: D72, E32, E65, K0, O4, P52, Z13

Keywords: trust, institutions, confidence, survey data, congress, banks, big business, media, courts

Corresponding author:

Betsey Stevenson

Business and Public Policy Department

The Wharton School

University of Pennsylvania

1454 Steinberg Hall-Dietrich Hall

3620 Locust Walk

Philadelphia, PA 19104-6372

USA

E-mail: betseys@wharton.upenn.edu

\footnotetext{
"Prepared for the AEA session "Law and Economics," organized by Steven Shavell, and chaired by Henry Farber, with Philip Cook serving as discussant. The authors would like to thank Philip Cook for helpful comments, Don Kohn for useful conversations, and John Coglianese for truly outstanding research assistance. The authors wish to disclose that they obtained access to data from the Gallup World Poll and from recent Gallup polls due to a consulting relationship with Gallup.
} 
This paper explores the link between two coincident events: The Great Recession, and the current high levels of mistrust the American people have for public institutions. We begin by documenting the recent sharp decline in the confidence the American public has in their government, financial and business sectors, and to a lesser extent, their media and their courts. We are motivated by our own casual empiricism which suggests that widespread mistrust has been an important constraint on policymakers attempting to pass expansionary macroeconomic policies in the wake of the Great Recession. We then assess whether this decline in trust is a standard cyclical response, whether it reflects other factors, or whether it is due to the specific character of the current downturn. There has been little research documenting whether trust varies with the business cycle, and indeed, Robert Z. Lawrence (1997, p.132) notes that "our understanding of the links between economic performance and trust leaves much to be desired." Our contribution therefore lies in our demonstration of how trust moves with the business cycle, using both data on the United States and cross-country comparisons.

\section{National trends}

We begin by analyzing data from a series of approximately annual Gallup surveys of Trust in Institutions. These surveys began in 1973 and typically ask around one or two thousand people each year: "Now I am going to read you a list of institutions in American society. Please tell me how much confidence you, yourself, have in each one." We focus on questions probing trust in Congress, the banks, big business, the U.S. Supreme Court and newspapers. Figure 1 shows the evolution through time of the proportion of the public who answer either that they either have "quite a lot" or "a great deal" of confidence in each institution. (Other allowable responses include "some" and "very little," and "none" is also occasionally volunteered.) This figure shows a long-run decline in trust in government, which has also been documented in data from the National Election Studies by Arthur H. Miller (1974), John R. Alford (2001) and Pew Research Center (2010). In recent years trust in Congress has declined again sharply, and it is currently at an historic low. Banks, however, were about as trusted in the early 2000s as 
in the 1980s, but the public's trust in banks has declined sharply in recent years, particularly during the global financial crisis. These data also point to longer-run declines in trust of the Supreme Court, big business, and newspapers, and in each case, this decline hastened over recent years.

\section{Figure 1: Confidence in Institutions in the United States}

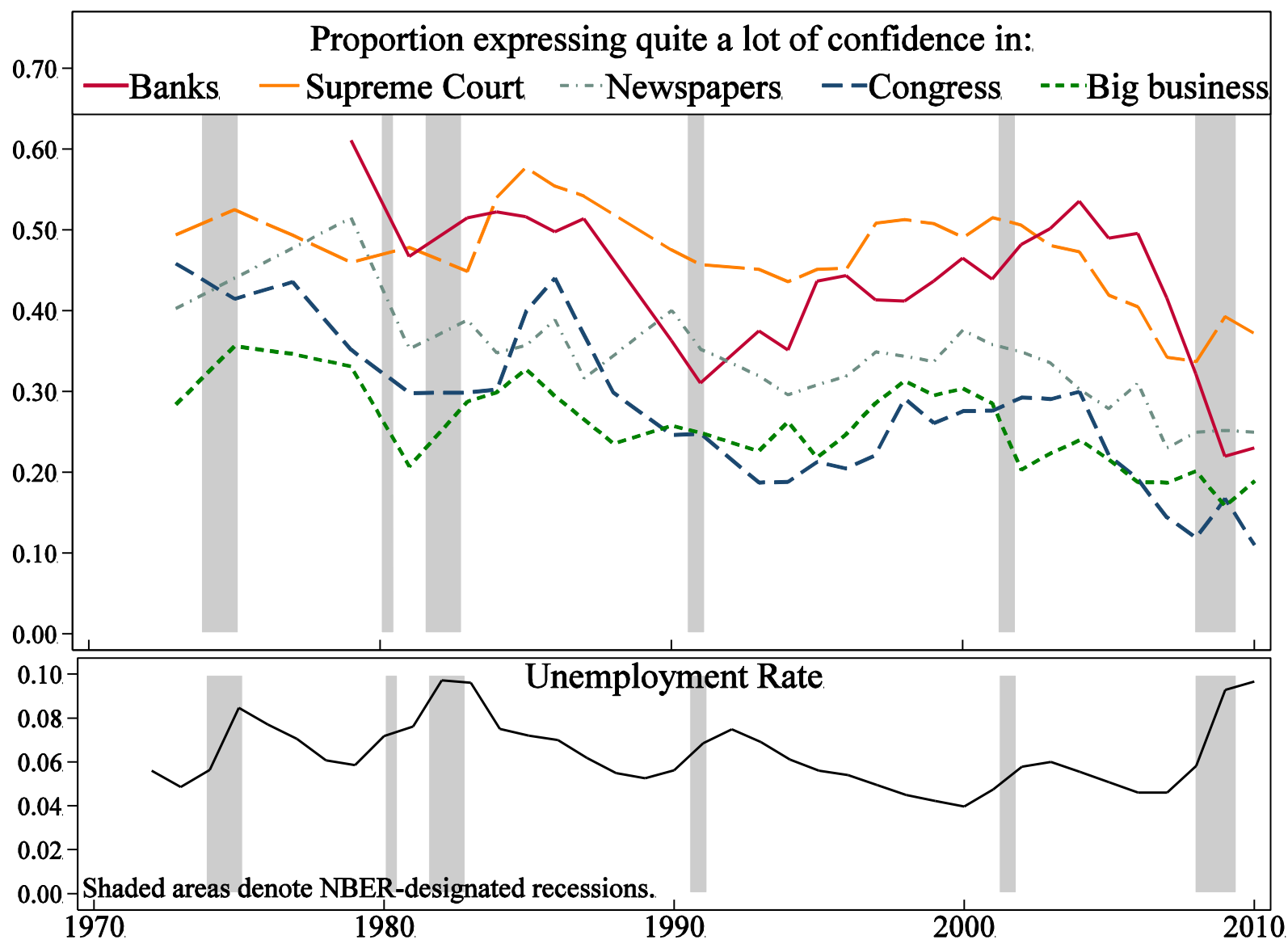

In order to test the aggregate time series relationship between public confidence in these institutions and the business cycle, we ran regressions of each measure of trust in institutions on a constant, a time trend, and the unemployment rate (and calculate Newey-West standard errors allowing for third-order autocorrelation). Table 1 reports the coefficient on unemployment from these regressions.

Panel A shows our analysis of responses from Gallup's surveys of Trust in Institutions. Panel B shows complementary results analyzing data from the Confidence in Institutions questions in the General 
Social Survey (GSS), which ask: "I am going to name some institutions in this country. As far as the people running these institutions, would you say you have: a great deal of confidence, only some confidence, or hardly any confidence in them?" Panel C shows results from yet another data collection, Gallup's Trust and Honesty polls, which ask: "Please tell me how you would rate the honesty and ethical standards of people in these different fields — very high, high, average, low or very low."

\section{Table 1: Cyclicality of Confidence in Institutions-U.S. Time Series}

\begin{tabular}{|c|c|c|c|c|c|}
\hline \multicolumn{6}{|c|}{$\begin{array}{l}\text { Panel A: Gallup Trust in Institutions data (1972-2010) } \\
\text { Denendent variable. Percent who have either "A great deal or "Ouite a lot" of }\end{array}$} \\
\hline & Congress & Banks & Big business & $\begin{array}{l}\text { Supreme } \\
\text { Court }\end{array}$ & Newspapers \\
\hline$\beta$ : Unemployment rate & $\begin{array}{l}-0.89^{* *} \\
(0.38)\end{array}$ & $\begin{array}{l}-2.67^{* * *} \\
(0.94)\end{array}$ & $\begin{array}{l}-0.77 \\
(0.56)\end{array}$ & $\begin{array}{l}-0.83 \\
(0.51)\end{array}$ & $\begin{array}{l}-0.84^{* *} \\
(0.37)\end{array}$ \\
\hline \multicolumn{6}{|c|}{$\begin{array}{l}\text { Panel B: General Social Survey, Confidence in Institutions (1972-2008) } \\
\text { Dependent variable: Percent who have "A great deal" of confidence in the people running: }\end{array}$} \\
\hline & Congress & $\begin{array}{l}\text { Banks \& } \\
\text { Financial } \\
\text { Institutions }\end{array}$ & $\begin{array}{l}\text { Major } \\
\text { companies }\end{array}$ & $\begin{array}{l}\text { US Supreme } \\
\text { Court }\end{array}$ & The Press \\
\hline$\beta$ : Unemployment rate & $\begin{array}{l}-1.36^{* * *} \\
(0.37)\end{array}$ & $\begin{array}{l}-1.62^{*} \\
(0.93)\end{array}$ & $\begin{array}{l}-1.46^{* *} \\
(0.65)\end{array}$ & $\begin{array}{l}-0.63 \\
(0.37)\end{array}$ & $\begin{array}{l}-0.39 \\
(0.51)\end{array}$ \\
\hline \multicolumn{6}{|c|}{$\begin{array}{c}\text { Panel C: Gallup Trust and Honesty data (1976-2010) } \\
\text { Dependent variable: Percent who rate the honesty and ethical standards of people in each field as above } \\
\text { average }\end{array}$} \\
\hline & Congressmen & Bankers & $\begin{array}{c}\text { Business } \\
\text { executives }\end{array}$ & & Journalists \\
\hline$\beta$ : Unemployment rate & $\begin{array}{c}-1.11^{* * * *} \\
(0.37)\end{array}$ & $\begin{array}{l}-1.40^{*} \\
(0.68)\end{array}$ & $\begin{array}{c}-1.23^{\text {*** }} \\
(0.33)\end{array}$ & & $\begin{array}{c}0.45 \\
(0.41)\end{array}$ \\
\hline
\end{tabular}

Notes: Each cell shows a separate regression with a different dependent variable, reporting the coefficient on unemployment from a regression: \%Confident in institution ${ }_{t}=\alpha+\beta$ Unemployment rate r $_{t}+\gamma$ Year $_{t}+\epsilon_{t}$. (Newey-West standard errors allowing for up to third-order autocorrelation in parentheses.) ${ }^{* * * *},{ }^{* *}$ and ${ }^{*}$ denote statistically significant at $1 \%, 5 \%$ and $10 \%$, respectively.

These regressions show that the public's confidence in each of these institutions is pro-cyclical.

The strongest effect is for banks, where the coefficient on unemployment is both statistically significant, and large enough to suggest that much of the recent decline in the confidence in banks seen in Figure 1 was in fact due to the recession. Specifically, the Gallup Trust in Institutions data show that the proportion expressing a great deal of confidence in banks fell from 42 percent in 2007 to 23 percent in 
2010. Over this period the unemployment rate rose by five percentage points, and thus the coefficient on unemployment reported in Panel A predicts a decline of 13.5 percentage points in the proportion expressing a great deal of confidence in banks.. Thus about two-thirds of the recent decline in trust is explained by the cyclical downturn. Similarly, the regression estimates in Panel C suggest that about half of the decline in the proportion who rate the honesty of bankers as above average can be explained by the corresponding rise in unemployment. While the coefficient in Panel B suggests a similar decline in the public's confidence in banks and financial institutions, the data are currently only available through 2008, so we don't know the actual change over the recession.

The pro-cyclical nature of trust in congress and members of congress is also statistically significant in all three datasets. The coefficients from Panel A predict that trust in Congress fell by about 4.5 percentage points as a result of the recent rise in unemployment, which is slightly larger than the actual decline experienced. The coefficient estimates in Panels B and C suggest similar declines. Trust in "major companies" and "business executives" are both significantly pro-cyclical and similar in magnitude to estimates for Congress, even as trust in "big business" estimated in Panel A yields a somewhat smaller and insignificant coefficient.

The three datasets yield more mixed messages about trust in "newspapers," "the press" and “journalists.” Panel A suggests a statistically significant decline in trust of newspapers when unemployment increases, but Panel B finds a smaller, statistically insignificant result and Panel C shows that the public's perception of the honesty of journalists actually falls. Finally, the two datasets probing trust in the Supreme Court each suggest that it is somewhat pro-cyclical, however both estimates are sufficiently imprecisely estimated as to be statistically insignificant.

While our estimates of cyclicality remain roughly similar if we omit data from the most recent few years, the most striking of our findings — about the cyclicality of trust in banks and bankers - rest heavily on the last few observations. More generally, with only thirty or fewer observations for each 
measure these findings are only suggestive. Thus we now turn to international comparisons to get a stronger sense of the effects of a deep recession on trust in institutions.

\section{International comparisons}

The Gallup World Poll is the only cross-national dataset assessing trust in public institutions that is published in a timely enough fashion that we have sufficiently recent data to assess the implications of the global financial crisis that began in 2008. The Gallup World Poll asks: "In [country], do you have confidence in each of the following, or not?" and then proceeds to list an array of institutions, including the "National government," "Financial institutions or banks," the "Judicial system and courts," and the "Quality and integrity of the media." The World Poll is typically an annual survey of around 1,000 people in each of up to 155 countries, although actual sample sizes vary by country, not every country is surveyed every year, and not every question is asked in each survey. The World Poll began in 2006, and the version of the dataset we are using (released on October 15, 2010) contains data through to 2010 for most countries and 2009 for others. We match each survey response with the unemployment rate (or in some cases, the forecast of unemployment) in the corresponding country and year, using the IMF's October 2010 World Economic Outlook database. This yields usable data for 98 countries.

Our simplest approach involves asking whether countries experiencing the largest change in unemployment also experienced larger declines in trust. Thus, we combine data from the 2006 and 2007 waves into a single pre-financial crisis observation, and data from the 2009 and 2010 waves are combined into a post-financial crisis observation. There were fewer countries included in the 2006 and 2007 Gallup World Polls and so we only observe trust before and after the crisis in 65 to 71 countries (depending on the trust question). Figure 2 graphs changes in the public's confidence in institutions against changes in unemployment.

These data point to a tight link between macroeconomic conditions and trust: In those countries in which unemployment rose most sharply, trust in both financial institutions and trust in national 
governments declined most dramatically. There is a less stark, albeit statistically significant relationship for trust in the judicial system, and no clear relationship between confidence in the media and unemployment.

\section{Figure 2: Changes in Public Confidence and Changes in Unemployment $2006 / 07$ to $2009 / 10$}

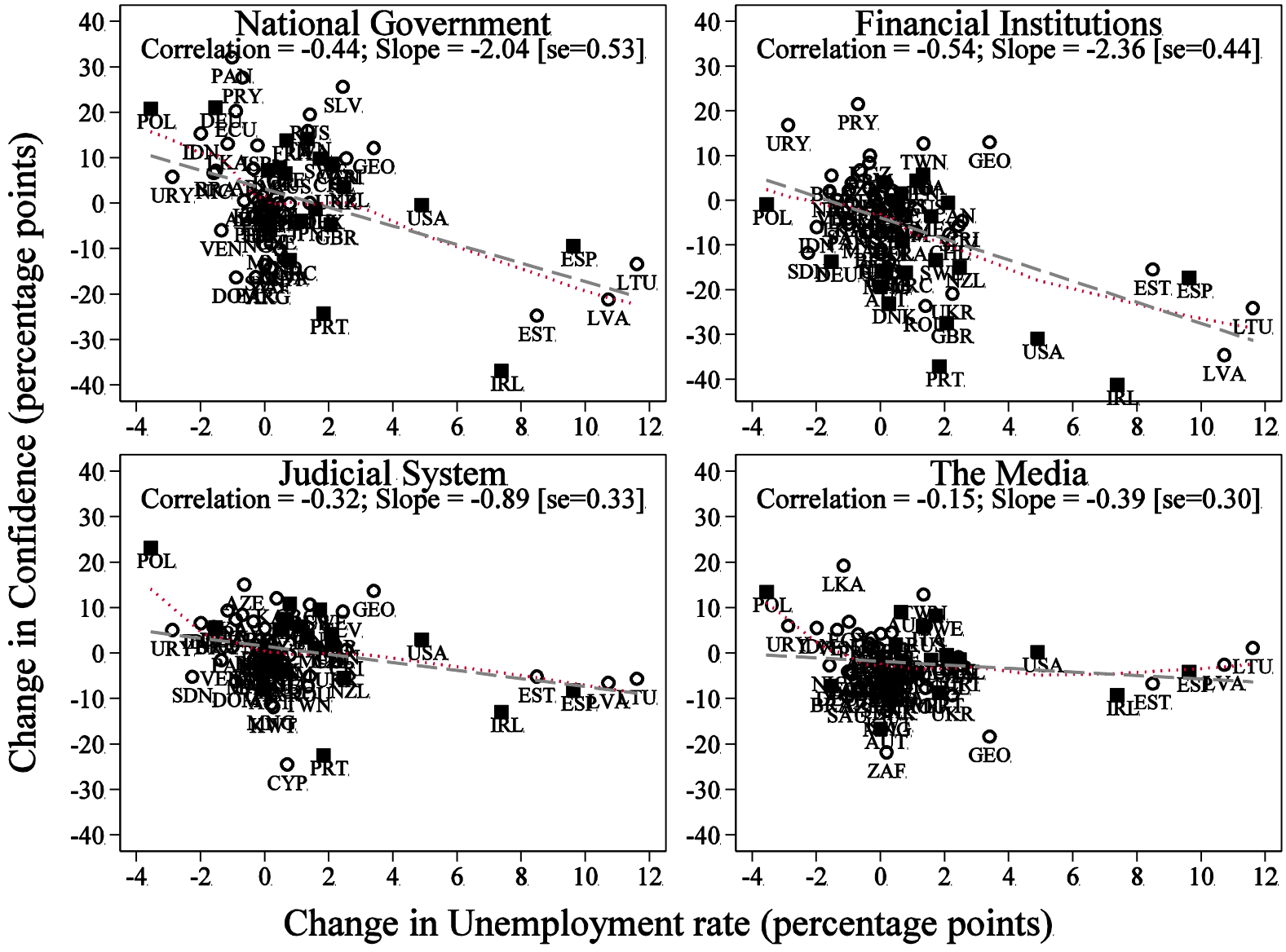

Notes: Changes in unemployment and trust are changes from before the global financial crisis (2006 and 2007) to after the crisis (2009 and 2010). OECD countries are shown as squares; other countries are shown with hollow circles. The reported correlation, slope the dashed OLS regression line and the dotted lowess fit are all calculated on the whole sample.

We investigate these results more systematically in Table 2, where we analyze the microdata directly. Panel A shows the average proportion of our sample who express confidence in each institution. In Panel B we report results of probit regressions of each trust variable on the corresponding unemployment rate in that country in that year (and clustering standard errors by country). This regression includes both country and year fixed effects, and also a saturated set of dummy variables for 
the respondent's sex, age, marital status, urban or rural status, and education ${ }^{3}$ We report the average marginal effects, and the coefficients are scaled so that they can be read as the change in the probability of expressing confidence in an institution, due to a one percentage point rise in the unemployment rate.

\section{Table 2: Cyclicality of Confidence in Institutions Around the World}

\begin{tabular}{|c|c|c|c|}
\hline \multicolumn{4}{|c|}{ Dependent variable: In [country], do you have confidence in each of the following, or not: } \\
\hline National government & Financial institutions & Judicial system & The media \\
\hline \multicolumn{4}{|c|}{ Panel A: Sample averages } \\
\hline $30.8 \%$ & $61.4 \%$ & $51.3 \%$ & $53.8 \%$ \\
\hline \multicolumn{4}{|c|}{ Panel B: Coefficient on Unemployment Rate (All countries) } \\
\hline $\begin{array}{c}-1.59^{* * * *} \\
(0.44)\end{array}$ & $\begin{array}{c}-1.93^{* * * *} \\
(0.37)\end{array}$ & $\begin{array}{c}-0.87^{\text {*** }} \\
(0.30)\end{array}$ & $\begin{array}{l}-0.20 \\
(0.26)\end{array}$ \\
\hline \multicolumn{4}{|c|}{ Panel C: Coefficient on Unemployment Rate (OECD countries only ) } \\
\hline $\begin{array}{c}-2.96^{* * * *} \\
(0.79)\end{array}$ & $\begin{array}{c}-2.25^{* * *} \\
(0.85)\end{array}$ & $\begin{array}{c}-2.01^{* * * *} \\
(0.78)\end{array}$ & $\begin{array}{l}-0.19 \\
(0.51)\end{array}$ \\
\hline
\end{tabular}

Notes: Sample is Gallup World Poll, 2006-2010. Each cell in Panels B and C reports the coefficient on unemployment from a probit regression: $I\left(\right.$ Trust $\left._{\text {ict }}\right)=\beta$ Unemployment rate $_{c t}+\gamma$ Year $_{t}+\delta$ Country $_{c}+$ Controls $_{i c t}+\epsilon_{i c t}$ where the controls include saturated dummies for the respondent's sex, age, marital, urban and education status (plus dummies for missing controls). Sample size ranges from 296,706 to 321,658 individuals, in panels A and B (which cover 93-97 countries), and from 94,197-96,205 (and 30 OECD countries) in panel C.

(Standard errors in parentheses clustered by country). ${ }^{* * *},{ }^{* *}$ and ${ }^{*}$ denote statistical significance at $1 \%, 5 \%$ and $10 \%$.

These results broadly confirm the patterns seen in Figure 2 and are consistent with what we saw in the US time series: confidence in financial institutions is very strongly cyclical, as is confidence in the national government. Unlike the US time series data, we see more robust evidence of cyclicality in confidence in the judicial system. Confidence in the media does not much move with the unemployment rate across countries. We have also run these regressions on data aggregated to the country-year level, and obtain very similar results.

Another robustness check was to consider whether these findings are being driven by developed or developing countries. One might be concerned that data from developing countries is not particularly informative for developed countries. Thus, in Panel C we estimate these effects separately for OECD

\footnotetext{
${ }^{3}$ When control variables are missing, we use the observation and include a dummy variable for missing information.
} 
member nations. Perhaps surprisingly, these results suggest that the link between confidence and unemployment is strongest in developed countries, and trust in the judicial system is particularly cyclical in these developed economies.

\section{State-Specific Business Cycles in the United States}

Finally, we return to our US data to assess whether the cyclicality in trust we observe in the national time series holds for state-specific business cycles. In each case, we run a probit regression explaining whether or not the respondent trusts that institution as a function of the state-wide unemployment rate in that year, and report the coefficient in Table 3. We control for both year fixed effects — which partial out the aggregate business cycle which identified the regressions in Table 1 - and also state fixed effects, which controls for persistent cross-state differences. Thus our regressions explore the relationship between trust and deviations of the state unemployment rate from the national average.

We also control for a saturated set of dummy variables for age, sex, race and education (with further dummy variables for missing values of each).

\section{Table 3: Confidence in Institutions and State-Specific Business Cycles}

\begin{tabular}{|c|c|c|c|c|c|}
\hline \multicolumn{6}{|c|}{$\begin{array}{c}\text { Panel A: Gallup Trust in Institutions data (1972-2010) } \\
\text { Dependent variable: I("A great deal or "Quite a lot" of confidence) in: }\end{array}$} \\
\hline & Congress & Banks & Big business & $\begin{array}{l}\text { Supreme } \\
\text { Court }\end{array}$ & Newspapers \\
\hline$\beta$ : Unemployment rate & $\begin{array}{l}-0.23 \\
(0.29)\end{array}$ & $\begin{array}{l}-0.06 \\
(0.43)\end{array}$ & $\begin{array}{c}-0.74^{* * * *} \\
(0.27)\end{array}$ & $\begin{array}{l}-0.07 \\
(0.30)\end{array}$ & $\begin{array}{c}0.25 \\
(0.34)\end{array}$ \\
\hline \multicolumn{6}{|c|}{$\begin{array}{l}\text { Panel B: General Social Survey, Confidence in Institutions (1972-2008) } \\
\text { Dependent variable: I("A great deal" of confidence in the people running): }\end{array}$} \\
\hline & Congress & $\begin{array}{c}\text { Banks \& } \\
\text { Financial } \\
\text { Institutions }\end{array}$ & $\begin{array}{l}\text { Major } \\
\text { companies }\end{array}$ & $\begin{array}{l}\text { US Supreme } \\
\text { Court }\end{array}$ & The Press \\
\hline$\beta$ : Unemployment rate & $\begin{array}{l}-0.09 \\
(0.24)\end{array}$ & $\begin{array}{l}-1.10^{* * *} \\
(0.22) \\
\end{array}$ & $\begin{array}{l}-0.56^{* *} \\
(0.29)\end{array}$ & $\begin{array}{c}0.11 \\
(0.34)\end{array}$ & $\begin{array}{l}-0.04 \\
(0.25)\end{array}$ \\
\hline \multicolumn{6}{|c|}{$\begin{array}{l}\text { Panel C: Gallup Trust and Honesty data (1972-2010) } \\
\text { Dependent variable: I(The honesty and ethical standards of people is above average) in: }\end{array}$} \\
\hline & Congressmen & Bankers & $\begin{array}{c}\text { Business } \\
\text { executives }\end{array}$ & & Journalists \\
\hline$\beta$ : Unemployment rate & $\begin{array}{l}-0.41^{* *} \\
(0.20)\end{array}$ & $\begin{array}{l}-0.16 \\
(0.35)\end{array}$ & $\begin{array}{l}-0.44 \\
(0.36)\end{array}$ & & $\begin{array}{l}0.93^{* * *} \\
(0.29)\end{array}$ \\
\hline
\end{tabular}


Notes: Each cell shows a separate regression with a different dependent variable, reporting the coefficient on unemployment from a probit regression: I(Confident in institution $)_{i s t}=\alpha+\beta$ Unemployment rate $_{s t}+$ $\delta$ State $_{s}+\gamma$ Year $_{t}+$ Constrols $_{i s t}+\epsilon_{\text {ist }}$. Controls include a saturated set of dummies for age, gender, race, and education status. (Standard errors in parentheses clustered by state.) ${ }^{* * *},{ }^{* *}$ and ${ }^{*}$ denote statistically significant at $1 \%, 5 \%$ and $10 \%$, respectively.

Consistent with earlier results (and with earlier results in Justin Wolfers (2003)), we see that in all three panels trust and confidence is pro-cyclical. However, in most cases the point estimates are substantially smaller than those estimated in the national time series or in the international data. The most consistent finding across the three panels is that relatively high state unemployment rates yield substantial and statistically significant declines in trust in "big business," "major companies" and a similar (albeit insignificant) decline in the perceived honesty of "business executives." While the largest effect is the pro-cyclicality of trust in "banks and financial institutions" in Panel B, surprisingly confidence in "banks" in Panel A is acyclical. This latter finding stands in contrast to estimates generated from our other approaches, and while we have probed this finding further, it does not seem to be driven by anything particularly unusual. The data describing perceived honesty in Panel $\mathrm{C}$ are consistent with our earlier findings for all occupations except journalism, as business executives, congressmen, and bankers each rank among the occupations with the most pro-cyclical levels of perceived honesty. Contrary to earlier findings, journalists are more likely to be perceived to be honest during periods of high unemployment.

\section{Discussion}

We have documented that trust in public institutions has declined in the United States over time and that this decline has accelerated over recent years, particularly following the recent financial crisis. The recent decline in the public's confidence in the financial sector is particularly large. Simple time series regressions - which we interpret as no more than suggestive-indicate that much of this decline may be attributable to the recent recession. More convincingly, cross-country comparisons confirmed that those countries which experienced the largest rise in unemployment also saw public confidence in both their national governments and the finance sector decline particularly dramatically. Taken together, 
these two sources of data suggest that much of the recent decline in confidence-particularly in the financial sector - may simply be a standard response to a cyclical downturn. Equally, our most compelling evidence comes from the international data, and given their limited history, those data may simply be telling us about this recession rather than recessions in general. It remains a useful topic for further research to see the cyclicality of trust in a panel of countries with a longer history.

Our analysis of several repeated cross-sections of confidence within U.S. states over the past few decades yielded a similar qualitative pattern — relatively lower trust in finance, big business and sometimes governments during periods in which a state has relatively higher unemployment. However, these patterns were not quantitatively as large, and were rarely statistically significant. We do not have a complete reconciliation of these findings, but should note that it seems plausible that state-specific shocks do less to undermine the confidence that the public has in what are essentially national institutions.

\section{References}

Alford, John R. 2001. "We're All in This Together: The Decline of Trust in Government, 1958-1996." In What is it about government that Americans dislike?, edited by John Hibbing and Elizabeth Theiss-Morse, 28-46. New York, New York: Cambridge University Press.

Lawrence, Robert Z. 1997. "Is It Really the Economy, Stupid?" In Why People Don't Trust Government, edited by Joseph S. Nye, Philip D. Zelikow and David C. King, 111-132. Cambridge, Massachusetts: Harvard University Press.

Miller, Arthur H. 1974. "Political Issues and Trust in Government: 1964-1970." American Political Science Review. 68 (3): 951-72.

Pew Research Center. 2010. Distrust, Doscontent, Anger and Partisan Rancor: The People and Their Government. Washington, DC: Pew Research Center for the People and the Press.

Wolfers, Justin. 2003. "Is Business Cycle Volatility Costly? Evidence From Surveys of Subjective Wellbeing." International Finance, 6 (1): 1-26. 